\title{
A Study on the Strategies of College Teachers' Teaching Ability Promotion Based on the Cultivation of Minority Talents
}

\author{
ZHU Xin-wu \\ (Xinjiang University Dean's Office, Urumqi Xinjiang China 830046)
}

\begin{abstract}
The quality of the minority personnel training is closely related to the teaching ability of college teachers. This paper firstly analyzes the restricting factors of university teachers' teaching ability. On this basis, the paper puts forward four strategies to improve the teaching ability of university teachers, which is to renew educational ideas, improve teacher evaluation system, strengthen the training of teachers' teaching skills and promote teachers' self - development.
\end{abstract}

Key words - training of ethnic minority tale; university teachers; promotion of teaching ability; strategy

At present, China's higher education is facing from "quantity expansion" to focus on "quality promotion and connotation development", how to promote ethnic education teaching reform, improve teaching quality, cultivate high-quality innovative compound minority new talent, in which the improvement of teachers' professional level and teaching ability is the basic guarantee. For a long time, there are some problems in our country's university, that is to pay attention to the teacher's scientific research level and despise the teaching ability, and attach importance to teachers' education and despise teaching ability, these problems seriously restrict the further improvement of the level of minority personnel training in Colleges and Universities. The improvement of College Teachers' teaching ability directly affects the effect of classroom teaching, students' knowledge and skills, the ability of autonomous and the cultivation of innovative thinking ability. Therefore, It is a very urgent task to improve the training quality of the minority nationality by effectively improving the teaching ability of university teachers.

\section{The CONSTRAints OF COLlEge TEACHERS' TEACHING ABILITY}

A. Lack of a profound understanding of the new concept in higher education

At the present stage, Chinese teaching in Colleges and universities still exist in the traditional spoon feeding methos, the teachers play the role of managers and commands in the teaching process, students are passive recipients. This is contrary to the teaching idea and teaching thought of talents training and students' all-round development, this is contrary to the new concept of classroom teaching, including the outstanding students' subject status and the main role, teachers are learners and collaborators, learning ways to promote autonomous learning, cooperative learning and inquiry learning, etc. At the same time, teachers also lack of systematic thinking on the teaching philosophy and teaching mode reform of minority students' cross cultural teaching, psychological adjustment and talent training. This situation has been unable to meet the requirements of the current national teaching reform, has seriously affected the teaching quality and the cultivation of innovative talents of the minority nationalities in colleges and universities.

\section{B. University teachers lack of systematic education and teaching skills training}

From the current situation, the training of teachers' teaching skills are affected by many factors: First, teachers' pre service training time is too short, the new teacher generally carried out only seven days to ten days of training; Second, the form and content of teacher training is not perfect, there is attention of academic education, professional knowledge and ability of scientific research training, education, theoretical knowledge and school policies introduced, the lack of 
teachers' teaching concept, value concept and the professionalism of the training and education, ignoring to the teaching practice of Teachers, educational technology and teaching skills training; Third, training methods only pay attention to the training of teachers in the classroom teaching experience, it can't meet the needs of the different disciplines of teachers, the training effect of the evaluation index is also relatively simple; Fourth, the teacher training system is not perfect, the lack of guidance on the teacher's personal career planning, and the teacher's training funds are lack. As the normal mechanism of teacher education teaching skills training has not yet been formed, it has greatly influenced the teaching ability of college teachers.

\section{Teachers' assessment and evaluation are lack of system}

At present, the lack of system of evaluation of teachers in Colleges and universities is mainly manifested in two aspects: First, the teacher's evaluation guide appears deviation. The evaluation of teachers in Colleges and universities is generally in the direction of "heavy research and light teaching", the evaluation of academic development and the evaluation of the quantity of teaching performance have negative effects on the teaching and development of teachers. University teachers pay more attention to the professional knowledge and ability of scientific research, and they lack the motive force for the development of teaching research and teaching ability. When colleges and universities evaluate the level of teachers' ability, university in the teaching ability of teacher evaluation, for the quality of teaching, teaching input and personnel training effect of the lack of effective evaluation, directly lead to teachers can not be at ease teaching. Second, there are problems of evaluation subject, evaluation criteria and evaluation results of teachers' teaching evaluation, this is not conducive to the teachers to obtain effective information of improve the teaching ability.

\section{THE STRATEGIES OF IMPROVING THE TEACHING}

\section{ABILITy OF COLLEGE TEACHERs BASED ON THE} PERSPECTIVE OF MINORITY PERSONNEL TRAINING

Universities and teachers should pay attention to and support the development of ethnic education, constantly promote the training mode reform of minority talents, improve the professional level of teachers and teaching ability.

A. Update the educational idea and teaching ideas, to adapt to the new requirements of cultivating ethnic minority talents

To promote the all-round development of students is essential purpose to enhance the development and teaching ability of teachers in universities, talent training is the core part of the reform of education and teaching in universities. Student development and personnel training is a complicated system engineering, related to the teaching content, teaching design, teaching organization and management, teaching method improvement factors, but the most important is to firmly establish the "student concept of the", that is, to establish " personnel training " and "students' full development" concept to a series of questions. Famous educator Speck (Speck) pointed out that the ultimate goal of the development of teachers is to promote student learning."Teachers in Colleges and universities should firmly establish everyone taught the students and all-round development education idea and teaching ideas, advanced teaching philosophy to guide the teaching reform and attach importance to cultivation of knowledge and ability of students, to encourage students to develop personalized, to stimulate students interest in learning, to cultivate students' active learning, lifelong learning consciousness and spirit, improve the students to gain knowledge, autonomous learning ability, guide the students to form the respect for others, integrity and responsible character. At the same time, we should vigorously carry out the "five views", "four identity" education, the ideological and political education throughout the whole process of personnel training, to maintain the unity of the motherland, to build of the oppose the national division of the ideological line of defense.

\section{B. To further improve the teacher evaluation system,} encourage and guide teachers into Teaching

First, to construct a kind of incentive mechanism which is conducive to stimulating the teachers' enthusiasm in teaching. By constructing a kind of the teaching as teacher's most important responsibility of teacher performance evaluation mechanism, optimization of the evaluation system of teaching 
quality and academic research, an appropriate increase in the proportion of teachers' performance appraisal and so on, guide teachers into the teaching reform and talent cultivation. Two is to enhance the evaluation results and feedback from the perspective of paying attention to teachers' teaching ability. According to the specific circumstances of the subject categories and subject level, job category and teachers rank, to take a combination of quantitative and qualitative, focus on assessment and comprehensive assessment of combination evaluation method, using the complementary relationship between leadership assessment, peer evaluation, supervision and evaluation and student evaluation, improved the mode of teaching evaluation, evaluation process is no longer a mere formality, evaluation system truly become the effective driving force to enhance the teaching ability of university teachers of college teachers' comprehensive evaluation.

\section{Actively carry out the training and guidance of teachers' teaching skills, improve the teachers' professional level}

One is the implementation of pre service training and guidance on new teachers. On the new teachers to carry out the teaching of career planning, teaching theory and teaching practice teaching skills as the main content of the system of teaching and training and guidance. At the same time, colleges and universities should establish new teaching system for teachers, after the strict examination, the qualified can engage in teaching. Two is on the job teachers to carry out training and guidance. Colleges and universities should organize all kinds of teaching activities, the old professor, teaching teachers and outstanding teachers hired on into the teaching, teaching design, teaching management, exchange of teaching and teaching research Thematic Lecture Series, improving teaching skills of teachers; through the development of young teachers teaching competitions, lectures and dispersion concentration to observe the discussion combining the teaching way to teacher training, teachers are encouraged to attend teaching seminars, teachers and peers, teachers share the advanced teaching idea and teaching skills. Three is to establish an effective teacher education, learning system, the full use of external advantages of teaching resources to train the school teachers, in a short time as soon as possible to improve their teaching ability.

D. To the problem based teaching research as the breakthrough point, to promote the development of Teachers

In the teachers' independent development process, teachers need to ponder and Research on the problems encountered in the teaching practice, teachers through the successful experience of teaching reflection can weaknesses and is conducive to the formation of teachers' personal teaching style, forming the core competitiveness of the teachers' teaching ability; can reduce errors through the analysis of the problems existing in the teaching, detours, to determine the direction of the growth of teachers' career, and eventually achieve the comprehensive and coordinated development of teachers' teaching ability.

\section{ACKNOWLEDGEMENTS}

This paper is the results of the stage of Xinjiang Education Science “12th Five-Year” planning subject "Xinjiang University minority talent training mode reform and research" (145060) .

\section{REFERENCES}

[1] QIAN Guo-ying, CUI Yan-qun. Combination of evaluation and training, and establish a sound development mechanism for teachers [J ] . China University education, 2012 (2):66-68.

[2] Speck, M, Best practice in professional development for sustained educational change [J] .ERS Spectrum, 1996. 